\title{
The Teacher's Role in Telecollaborative Language Learning: The Case of Institutional Integrated Teletandem
}

\section{o papel do professor na aprendizagem telecolaborativa de línguas: o caso do Teletandem institucional integrado}

Suzi M. S. Cavalari*

*Universidade Estadual Paulista (UNESP), São José do Rio Preto, São Paulo / Brasil smscavalari@gmail.com

https://orcid.org/0000-0001-7748-8516

Solange Aranha**

**Universidade Estadual Paulista (UNESP), São José do Rio Preto, São Paulo / Brasil

**Fundação de Amparo à Pesquisa do Estado de São Paulo (FAPESP)

solangeibilce@gmail.com

https://orcid.org/0000-0002-8092-1875

RESUMO: Teletandem é um modelo de telecolaboração em que pares de falantes de duas línguas diferentes se encontram virtual e regularmente para aprenderem a língua um do outro. $\mathrm{O}$ objetivo deste trabalho é discutir as implicações pedagógicas de se integrar a prática de teletandem ao syllabus de uma disciplina de língua estrangeira, enfocando o duplo papel do professor: ensinar língua inglesa nas aulas presencias regulares e mediar a aprendizagem virtual autônoma e colaborativa em teletandem. Diários de aprendizagem, produzidos por estudantes de inglês como língua estrangeira de um curso de Letras, foram coletados durante oito semanas no projeto de teletandem institucional integrado entre uma universidade britânica e uma universidade brasileira. A análise tem como foco o papel do professor na mediação da aprendizagem de língua estrangeira tanto em sala de aula como nos diários. Apresentamos evidências de como a ação do professor influencia na prática de teletandem ao mesmo tempo em que as aulas de inglês auxiliam na aprendizagem telecolaborativa autônoma.

PALAVRAS-CHAVE: aprendizagem telecolaborativa; teletandem institucional integrado; papel do professor.

ABSTRACT: Teletandeem is a model of telecollaboration in which pairs of speakers of different languages meet virtually and regularly in order to learn each other's language. The purpose of this paper is to discuss the pedagogical 
implications of integrating teletandem into the foreign language syllabus, focusing on the professor's dual role: teaching English in regular face-toface lessons and mediating virtual autonomous and collaborative learning in teletandem. Learning diaries, produced by EFL students from a Language Teacher Education course, were collected during eight weeks of an institutional integrated teletandem project between a Brazilian and a British university. Our analysis focused on the teacher's role in mediating foreign language learning both in the classroom and through the learning diaries. We present evidence on what the professor does so that teletandem practice can contribute to language learning in the classroom and, by the same token, how EFL lessons can aid in autonomous telecollaborative learning.

KEYWORDS: telecollaborative learning; institutional integrated teletandem; teacher's role.

\section{Introduction}

Institutional integrated teletandem (iiT'TD) was defined by Cavalari and Aranha $(2016,329)$ "as a series of teletandem sessions that are embedded in regular foreign language (FL) lessons (thus mandatory) so that such lessons both feed and are fed by teletandem practice." Such modality of teletandem practice was first implemented at UNESP in São José do Rio Preto (SJRP), Brazil, in 2011, when telecollaboration was integrated into the EFL syllabi of Languages and Literature, and Translation Studies majors. This change in syllabus can be considered a turning point in these majors, which became a blended or hybrid learning setting, and at the same time produced a great change in teletandem practice, which fit perfectly within the pre-existing curriculum.

Considering that teletandem guiding principles (autonomy, reciprocity, and separation of languages) remained the same, a number of studies on iiTTD have been carried out since then. Cavalari and Aranha (2016) proposed that there are three key procedures that are the teacher's responsibilities: (i) preparing learners by means of a tutorial, (ii) blending teletandem oral sessions (TOSs) into the FL syllabus by means of integrating tasks, and (iii) incorporating various assessment practices (self-assessment, peer assessment, and teacher assessment). The tasks, as pointed out by the authors, are related to what students do as they participate in iiT'TD: answering questionnaires (initial and final), participating in the tutorial and in the TOSs, writing learning diaries, and writing and correcting texts in a collaborative way. It should be noted that these tasks are instruments that the teacher can use to mediate learning, as well as monitor and assess students' progress. 
Within such a pedagogical setting, Bonfim (2014) investigated autonomy and showed that the integrating tasks may foster autonomous learning by offering support to students during the process. Brocco (2014) and Aranha and Cavalari (2015), who investigated asynchronous peer feedback offered by Brazilians to their partners' written productions in Portuguese, focused on the types of feedback and linguistic items addressed in text revision. Freschi (2017) studies the oral feedback offered during TOSs. These studies illustrated the formative purpose of peer assessment in iiTTD and the opportunities for collaborative learning during TOSs due to the accomplishment of the collaborative writing task. Cavalari (2016) examined a synchronous writing collaborative task from the Brazilian learners' perspective. The study revealed that, in those participants' views, they (i) learned different language aspects (vocabulary, sentence structure, register) while writing synchronously with their partners and (ii) believed their final text was improved by the synchronous collaborative experience. Based on the activity theory, Luvizari-Murad (2016) describes the tasks as instruments that this integrated modality generates.

These studies shed light on important aspects that are engendered as an autonomous and telecollaborative learning experience, which is incorporated into the English as a Foreign Language (EFL) syllabus. They focused on the FL learner's actions and perceptions, as well as on how students deal with (i) autonomous learning (BOMFIM, 2014), (ii) collaborative writing (CAVALARI, 2016) and tasks as learning instruments (LUVIZARI-MURAD 2016), and (iii) peer feedback (BROCCO, 2014; ARANHA; CAVALARI, 2015). However, such investigations are not concerned with the challenges that teachers may face as they try to create an interdependent relationship between teletandem and classroom practices. In this paper, we aim to discuss the pedagogical implications of integration in the form of teletandem implemented at UNESP-SJRP by one professor who performs a dual role: teaching English in a language and literature major (a language teacher education program) and mediating teletandem learning. Due to this dual role, the terms professor and teacher-mediator are used interchangeably when we are dealing with the data investigated in this study. Among the integrating tasks proposed by Cavalari and Aranha (2016), we investigate how the professor uses the diaries to blend classroom and teletandem practice. 


\section{Aspects of integration}

Taking into account that teletandem is a "mode of telecollaboration" (TELLES, 2015, 604), we believe that a dialog among research results based on different modes of implementation of collaboration must be established. Our interest falls specifically within how other telecollaborative projects have been integrated into university FL programs. In this respect, several researchers (LITTLE; BRAMMERTS, 1996; LEWIS; WALKER, 2003; O'ROURKE, 2007; FURSTENBERG; LEVET, 2010; O'DOWD, 2013; LEWIS; O'DOWD, 2016) who have been investigating this topic argued that integration can bear innumerous pedagogical benefits as well as obstacles. In terms of benefits, all these studies bring corroborating evidence that telecollaborative exchanges can be a powerful learning instrument when integrated into the FL curriculum and given adequate institutional support.

Calvert (1996) and Lewis (2003) investigated integrated etandem ${ }^{1}$ exchanges via email, and their studies revealed that successful integration involves preparing learners, offering support (both pedagogical and technological), and finding ways to achieve accreditation. Lewis (2003) investigated the Sheffield Tandem learning module as an accredited element of the undergraduate curriculum. The author presents the preparatory (or initial phase) as the one in which the principles and guidelines are presented to learners. He also describes the kinds of support that learners received in the Sheffield tandem integrated module in terms of instruments and procedures. He points out that learner diary offers students a framework for initial orientation (identifying learning needs and setting objectives) and a regular opportunity to reflect on and monitor their own learning. It also forms the basis for an advisory session with a language tutor who helps students in this initial phase. He also says that counselling session happens in the middle of the semester and aims at assisting the tandem pair. Besides, "tandem social" gives an opportunity for all the students on the module to exchange ideas and further support is offered by means of a scheduled session with a language adviser who is available once a week.

\footnotetext{
${ }^{1}$ According to Lewis (forthcoming), "the term 'tandem learning' is used to refer to the practice of foreign language learning using bilingual partnerships, whether face to face or online, while 'e-tandem learning' specifically designates exchanges taking place online, whether asynchronously, or synchronously, using such tools as email, text chat or webconferencing."
} 
That study also presented the types of assessment instruments used in the Sheffield model: two self-assessment tasks, one peer-assessment task, and two others (the learner diary and a recorded speaking test), which were assessed by the tutor. The author points out that each instrument was worth a different value, and the relative weight of each assessment tool is highly dependent upon institutional demands and constraints.

Still considering tandem tenets and the use of emails, as well as synchronous communication tools (chats) for the exchanges, O'Rourke (2007) remarks that, as teachers incorporate etandem into FL courses, it is important to leave enough time and space for learners to "converse freely" so as not to dilute the autonomous nature of this learning setting.

Over the years, as technology has evolved and offered different possibilities for communication, other tools have been incorporated into telecollaborative exchanges and new perspectives on how to characterize the pedagogical setting have been employed. In this sense, Furstenberg and Levet (2010) described an integrated telecollaboration project as a blended environment that includes a classroom and an online component. In their study, they focused on the interplay between online (by means of website materials and discussion forums) and classroom work, showing how both components harmonize to create a coherent whole.

Nissen (2015) also aimed at examining blended environments constituted by face-to-face lessons and telecollaborative exchanges. She analyzed and compared the designs of six blended courses of this nature in order to investigate (i) which of the learning modes (online or face-to-face) takes the lead (or dominant) and which one is complementary, and (ii) how tightly the modes are integrated and interwoven. The results showed that a common feature of all six courses is that the OIE [online intercultural exchange] mode is the central component of the design, with the face-toface sessions being devoted mostly to preparatory and analytical activities related to the virtual exchange.

a common feature of all six courses is that the OIE [online intercultural exchange] mode is the central component of the design, with the face-toface sessions being devoted mostly to preparatory and analytical activities relating to the virtual exchange. (...) these courses integrating OIE fully meet a key design principle for BL [blended] courses that several authors claim with reference to Vygotsky's Cultural-Historical Theory (Chew et al. 2008; Garrison and Vaughan 2008; Nissen 2014): facilitation through online interaction with peers and a tutor. (NISSEN, 2016, p.190). 
This investigation still addresses assessment in blended learning courses. The author remarks that the two learning modes should be considered in assessment practice and that there are several factors constraining choices of evaluation methods, such as the teaching approach, students not being used to formative forms of assessment, and the number of students to be assessed.

Besides these internal factors involved in blending telecollaborative practice within a foreign language course, it is crucial to consider the importance of telecollaboration for "virtual mobility", as proposed by the European Commission Glossary (2008) and discussed by O'Dowd (2013). The author argues that "blended telecollaborative" learning not only involves the blending of online and classroom activity but also the blending of telecollaborative exchanges with other issues at an institutional level - such as 'internationalization, physical mobility, and the institution's external profile" (p. 48).

All these internal and external factors come into play in various and complex ways, which may generate great challenges to the successful implementation of integrated modalities of collaborative learning. In this sense, O'Dowd (2013) reports the results of a survey that showed the obstacles mentioned by experienced practitioners of such learning settings, (i) time necessary to set up and run exchanges, (ii) difficulties in integration and assessment due to institutional requirements, (iii) lack of pedagogical knowledge about how to run and integrate exchanges, (iv) teachers' lack of e-literacies and required technological knowledge, (v) difficulty in finding appropriate partners.

These challenges seem to reveal a tension between institutional requirements and pedagogical implications of integrated telecollaborative practice, and we believe that it is the role of the teacher to seamlessly weave all these threads together (preparing, supporting, assessing learners in a blended environment, and establishing institutional accreditation), and to ensure that all this work makes a coherent whole both internally - for pedagogical purposes - and externally - for political and institutional reasons.

In teletandem context, the role of the teacher has usually been investigated within non-integrated settings (VIEIRA-ABRAHÃO, 2010; SALOMÃO, 2011, 2012; ANDREU-FUNO, 2015; FUNO; ELSTERMANN; SOUZA, 2015), i.e., one in which teletandem sessions 
are not classroom-integrated. This role has been performed by the teachermediator (TELLES; VASSALLO, 2006) during mediation sessions, which Leone and Telles (2015, p. 245) define as:

moments that follow interactions in teletandem. During these sessions, students have the opportunity to dialogue and exchange experiences with a mediator - a teacher of foreign languages. These discussions focus on (a) aspects of language, (b) culture and (c) partners' relationship. The mediation activity aims at giving students a teacher supported context (scaffolding) to reflect on the teaching and the learning experiences during the teletandem sessions.

Vieira-Abrahão (2010) and Andreu-Funo (2015) argue that mediation in teletandem relates to the concept of mediation within the Zone of Proximal Development (ZDP), as proposed by Vygotsky (1978), i.e., the distance between what the learner can do without assistance and what he can do with the assistance of a more competent peer (or a tutor). The authors state that the teacher may act as a mediator when they offer pedagogical support during the autonomous and collaborative learning experience in teletandem. Andreu-Funo (2015) also points out that the teacher-mediator performs multiple roles as he (i) observes learners during TOSs, (ii) verifies if the technology is working properly, (iii) reads participants' diaries, (iv) takes notes and registers important topics for discussion, (v) raises questions, and (vi) shares experiences. Despite the fact that these results were drawn from investigations within non-integrated modalities of teletandem, these considerations about the concept of mediation and the roles of the teachermediator may bring contributions to studies carried out within an integrated modality as well.

Aranha and Leone (2017) understand that the teletandem context is composed of two macro-tasks (which are recurrent and common to most groups): the TOS and the mediation session. The latter has the purposes of raising awareness about one's own learning process and discussing ways of dealing with the challenges faced by partners during TOSs. In fact, mediation sessions, described by Vieira-Abrahão (2010), Salomão (2012), and AndreuFuno (2015) may be considered a locus for discussing learning difficulties, sharing discoveries, promoting reflection, and alleviating anxiety and/or dissatisfactions. In Aranha and Leone's (2017) terms, mediation is a macrotask with two main purposes - orientation and reflection - composed of several 
microtasks which are group specific. At UNESP-SJRP, the microtasks related to reflection are face-to-face encounters and reflexive diaries.

Lewis (2003), Silva (2014), and Dooly (2015) have already mentioned the diaries' potential in assisting learners in integrated telecollaborative practice. Based on these studies, we understand that the participants' diaries can improve mediation sessions by generating questions that may not appear in a group discussion, but must be approached because of their importance for one's learning process. As already pointed out by Furstenberg and Levet (2010, p. 324), "discussions in class enable students to situate themselves in relation to others, to take hold of similarities and differences in personal opinions and reactions within the group, and to start identifying the many and complex factors influencing their attitudes." In our context, students write diaries after each TOS and are given professor's feedback before the following session, which implies a one-to-one dialog that enables the professor to follow the student's process. We argue that a combination of one-to-one dialog through diaries and class discussion may enrich both EFL lessons and the telecollaborative experience in iiTTD.

\section{Method}

This qualitative interpretative study is based on the data generated by the Brazilian professor's notes and her learners' diaries written in English in the first semester of 2016 within the iiTTD modality carried out between UNESP-SJRP and a British university. We focus only on what happens in the Brazilian classroom because British students are not required to perform this microtask. The activities do not necessarily match in both groups, since the level of students and the professor's approaches can be different. The Brazilian participants were 12 students, all native speakers of Portuguese, 19 to 21 years of age, attending the third year of a four-year major in Language and Literature Teacher Education, and their teacher-mediator, who is also one of the authors of this study. All students signed the consent form for data use. Teletandem practice was integrated into the EFL course, which involved two weekly lessons of two hours each. Out of a total of 120 hours, distributed in 15 weeks each semester ( 30 weeks total in a year), 32 hours (eight weeks per semester) were devoted to teletandem practice. Similar to Nissen's (2016) context, this blended proposal included face-to-face lessons - two hours a week - and telecollaborative exchanges - one hour of 
oral session and one hour dedicated to microtasks that support mediation (writing diaries and oral mediation group sessions), as proposed by Aranha and Leone (2017).

The students had a tutorial in the beginning of the semester with the intent of (i) presenting the guiding principles, the procedures, and tasks involved in teletandem, and the calendar, (ii) elucidating how the practice would be integrated into the lessons, how tasks were supposed to be developed and were going to be graded, and (iii) informing about the content of texts they were supposed to write, to exchange with their partners, and to discuss during sessions. There were three texts written in English based on topics related to the syllabus in each semester.

The data collection instruments used in this study were the professor's notes and the learning diaries written by the Brazilian participants after each TOS. Each student was given initials to preserve their identities: A, B, DS, F, G, M, N, O, P, R, S, Z. These diaries served as a tool for the professor to: (i) be aware of the difficulties students were facing at linguistic, cultural, and interpersonal levels; (ii) establish pedagogical procedures to approach recurrent topics in class; (iii) suggest individual consultation as the professor responded to each of the diaries each week. Cavalari and Aranha (2016) call these diaries "reflexive diaries". The diaries used in this study were written in Google Docs ${ }^{\circledR}$ by the participants and then shared with the professor by means of a folder created on Goolge Drive ${ }^{\circledR}$. The professor used the revision tool to give feedback. At the end of the iiT'TD experience, the teletandem laboratory assistants were responsible for downloading and saving them in a Word file format for research purposes. The diaries were given weekly feedback by the professor and recurrent issues were discussed in the mediation sessions, which were held during regular FL lessons. We decided to use the final (revised) version of the diaries whenever the learner accepted the suggestions made by the professor. If the learner did not accept the revision, we present the original version of his/her diary.

\section{Data analysis}

We present fragments of learners' diaries in relation to (a) the professor's feedback and further actions and (b) students' perceptions about their own learning in ii'TTD. We discuss the pedagogical implications of mediating learning through diaries for EFL lessons and teletandem 
practice, taking into account that, as proposed by Cavalari and Aranha (2016, p. 329), integration implies that "lessons both feed and are fed by teletandem practice". We intend to evidence a double role performed by the professor, for she used learners' diaries in iiTTD to meaningfully incorporate autonomous and telecollaborative learning aspects into regular FL faceto-face lessons and to realize how other integrating tasks are perceived by learners. We also intend to discuss how the teacher-mediator's actions and decisions may reveal the interplay of these two roles.

\subsection{What the teacher-mediator does so that teletandem practice feeds the FL lessons}

In this part of the analysis, we focus on what the professor does so that teletandem practice can contribute to language learning in the classroom. She read all of the 12 learners' diaries on weekly basis during eight weeks. The first pedagogical procedure used by the professor as she read the diaries is concerned with her provision of feedback to the learners' most frequent linguistic inaccuracies. Fragment 01 refers to B's report on how she dealt with a gap in her vocabulary during the TOS and to the type of corrective feedback offered by the professor:

\section{Fragment 01}

I had to take off my WISDOM TEETH, what was too difficult to explain and she had to ask to her teacher because I hadn't have no idea of how to say could I said that in Eenglish and I wrote to her "dente do sizo ou dente do juizo" and she called claim her teacher to read and asked said how we could say said that in Eenglish, and so I learned a curious and new word. (B, diary I).

The fragment shows that, as the professor reads the diaries, she provides linguistic feedback by means of the "suggesting" feature in Google Docs ${ }^{\circledR}$, which allows edits to become suggestions that may be accepted by the author. This fragment shows exactly what the diary looked like when the professor suggested revisions in Google Docs ${ }^{\circledR}$. By using that, the professor gives students a chance to check their deviations and revise their own texts later.

Revising the students' diaries in terms of linguistic inaccuracies has not been explicitly mentioned by researchers as one of the roles performed by the teacher-mediator in teletandem learning. In iiT'TD, however, it seems a 
coherent pedagogical procedure, for it brings together both the students' and the professor's perspectives of the learning gaps to be overcome. Because the feedback is individualized and private, it is not likely to threaten the learners' face and may be regarded as a meaningful learning opportunity to implement a formative assessment, i.e, the one that focuses on learning and not on classifying or grading.

Giving one-to-one private feedback was also used to offer affective support. In fragment 02 , B (a student who had been facing problems throughout the course) mentions her learning about the specificities of certain terms. We can see the professor's comment by the end of the diary (in italics) with the intention to express her empathy to the students' sense of discovering something new:

\section{Fragment 02}

She also explained to me that there is a difference between to be ill and to be sick, what I never minded. She told me when you are sick, you just have a cold, you are retching, and when you are ill it is like you have Cancer or something more serious. (B, diary IV). To tell you the truth, I didn't know that either. (-)

One-to-one professor's feedback also gives opportunity to raise students' awareness about certain learning issues that are usually addressed superficially in their diaries, as fragment 03 shows:

\section{Fragment 03a}

I wasn't sure of some information about the pronouns, because she asked me very specific uses, in very formal texts, so I had to think about and try to write her doubts to see if it was right or wrong. So, for me, this experience was a little difficult, I didn't know some points, but this was good because it made me stop to research, and it was an experience that can happen with me when I give classes, so the shock was good to show me how to deal with these kind of situation. (P, diary II)

This fragment reveals P's awareness both about the supporting role she performs during the part of the TOS when participants are speaking Portuguese, and the challenges that a foreign language teacher may face. The professor's comment by using the comment feature of Google docs shows how participating in a telecollaborative environment may be a pivotal experience to a FL teacher-to-be more evident. 


\section{Fragment 03b}

Teletandem is a very good place to make us think about our future role as teachers and how we can deal with real situations of teaching.

Besides this personalized feedback, the professor also uses diary contents to collect relevant points to be addressed in face-to-face lessons every week, which consists of the second pedagogical procedure we focus on in this analysis. Based on P's diary (fragment 03), in one of the following lessons, the professor discussed the challenges of becoming an FL teacher and the kinds of competences that are expected or desirable of such a professional. As predicted by the syllabus, it is crucial that these participants, as pre-service teachers, have opportunities to reflect and share experiences about what it means to teach a foreign language and Portuguese as a foreign language.

As well as the topic addressed in fragment 03, there were others considered intrinsically relevant by the professor, such as: (inter)personal challenges faced by learners, vocabulary, grammar, and culture related topics. These matters were mentioned in the diaries by students and used by the professor to foster group discussion and share learning experiences in class. In this sense, we believe that every lesson is a potential mediation session in which the contents to be addressed may be relevant not only to teletandem practice, but also to FL learning within the undergraduate course these students are taking.

Fragment 04 illustrates the motivation to discuss learners' struggles and feelings during TOSs:

\section{Fragment 04}

I told [name of the British participant] that in Minas, we have "cachoeiras" and I know that I have learned it in English once in my life but I didn't remember. So she told me that is "waterfalls", and I felt dumb, it is an easy thing. (B, diary III).

Based on this diary, the professor argued in the classroom that "feeling dumb" is part of the learning process. She discussed with the group that one of the aspects of autonomous learning is realizing what we do not know so that we may find strategies to improve that very aspect. She also pointed out that this is precisely one of the purposes of writing diaries within the 
teletandem practice, i.e, developing awareness about achievements and limitations in the learning process, recognizing strategies, and acquiring new competences.

As students presented the topic "learning vocabulary" in different ways in their diaries, the appropriateness of language use concerning different contexts and genres were approached in face-to-face lessons. Fragment 05 is related to vocabulary misuse:

\section{Fragment 05}

Today we talked about my text, an interview that I had written and sent her. I could see that most of my mistakes were because of the use of "graduation", I wrote this word to refer to a university student, and she didn't understand, because this word means the day that you finish your graduation, and I didn't know this, so my text was a little confusing. (P, diary III).

P's diary provides the professor with input to debate the importance of precision and accuracy in using register in different contexts, which, though not explicit in the syllabus, is an intrinsic argument of a language teacher education program. In fact, the professor used the diaries to share interesting "discoveries" made by individual students during TOSs with the rest of the group.

In terms of grammar, diaries contributed with several items to be addressed in class. M's diary calls attention to one of the grammar topics in the syllabus - complex sentences - and is used by the teacher-mediator to approach the topic. Prepositions and determiners were also mentioned as items to be revised:

\section{Fragment 06}

We talked about my epiphany. She corrected my test and gave some tips, for example: I can't use a verb like to find without the object. She explained the difference between other and another and where can I use them. She also explained the difference between near and close, which I didn't know. (M, diary 5).

Also related to grammar, Z's diary motivated a discussion on morphology, a content predicted in the syllabus and usually considered an arid topic by students. 


\section{Fragment 07}

He explained me too that there is a difference between vanity and vain: vanity is noun and vain is adjective and for what I was trying to say I should use vain. (Z, diary 5).

Although morphology was one specific grammar topic to be addressed that year, it was scheduled for the following semester. Contents of diaries like the one above dislocated the topic to the first semester in order to clarify language inadequacies partners were pointing out in Brazilian students' writings. This interplay between grammar issues mentioned by learners in their diaries and the foreign language program is critical in making teletandem an integrated practice.

Register was a topic that was implicitly predicted by the syllabus of the 3rd year, and addressed in face-to-face lessons after learners mentioned this topic in their diaries.

\section{Fragment 08}

(...) he said that my text was too informal and I shouldn't say "sucks", so I told him that it was an informal text, so it was ok. Actually, he added that if an "old person" read that she probably wouldn't like that and I disagreed because my grandmother, for example, says that type of thing all the time. (Z, diary V).

\section{Fragment 09}

She gave me many tips about vocabulary usage due to the fact that I mixed formal and informal registers in the same text, which seems unnatural for a native in English to read. (S, diary III).

We believe the most important aspect of this pedagogical procedure (using topics addressed by learners' in their diaries as contents for face-toface lessons) is the fact that the teacher-mediator creates a link between what the students perceive in relation to their learning during TOSs, and what the syllabus predicts that they should learn (or should have learned), trying to make the teaching-learning of these contents more meaningful. This pedagogical procedure may also ensure that, as pointed out by Furstenberg and Levet (2010) and Nissen (2016), both modes (the face-to-face and the online exchanges) of the course create a harmonious and coherent whole.

The diaries also informed the professor about some cultural topics that were relevant for further discussion in class. Data found in these diaries 
revealed evidence of what Telles, Zakir, and Funo (2015, p. 374) called culture-related episodes - "any part of a dialogue in which the focus is on explanations, questions or curiosities about a participant's own culture or their partner's culture". The following fragments illustrate some moments that highlight the intrinsic role of culture in telecollaborative language learning:

\section{Fragment 10}

She also told me about their holidays, the period of tests, the application of the tests, that it is very rigid. I think this is very interesting, we noted many differences between these aspects here in this university and where she studies. There are countless divergences, and talk about them is interesting, because sometimes we start to think it was the opposite, sometimes we prefer the way that the things are in the other country or university. (P, diary IV).

\section{Fragment 11}

She thought Brazilians weren't conservative because of the carnival, bikinis, beaches, weather, and all these stereotypes, but I tried to explain to her that the things are not so easy like that. We are a big catholic country and most part of the transsexuals work as dancers or prostitutes. A large number of Brazilians say that they don't have prejudice, but they don't want gays or transsexuals taking place and working as teachers, or doctors or any other profession. She got sad and said that in [name of the British city in which the foreign partner lives] transsexuals study and work everywhere. (M, diary IV).

The parts in italics indicate different perspectives on culture being addressed by these learners in TOSs - one that emphasizes the contrasts between the two cultures (we noted many differences) and one that deals with stereotypes and their implications within telecollaborative learning (She thought Brazilians weren't conservative because of the carnival, bikinis, beaches, weather, and all these stereotypes). In class, this topic was approached by means of advertisements and news that perpetuate stereotypes and that foreigners have access to. One of the aspects students raised during the group discussion was the social responsibility they had as partners to show the other side of the coin. In her diary, M emphasizes that she tried to explain stereotypical views (I tried to explain to her that the things are not so easy like that), but, at the same time, what she says 
reinforces the stereotypes (most part of the transsexuals work as dancers or prostitutes). Being aware of what we say and the effects it may have on others were two of the aspects discussed in the face-to-face lesson because of this specific diary.

If we consider that culture is materialized in how we use language, the following fragments also illustrate a relevant controversy expressed by various diaries, concerning the dichotomy British $\mathrm{X}$ American, as the following excerpt shows:

\section{Fragment 12}

We talked about language, dialect and accent the hole interaction which I think it made the interaction really productive; for example, I learned the words "accent" and "dialect", which I did not know before. He also explained how accent is associated with social class in England, how people are discriminated based on the way they speak and how the dialect changes to the center of London for smaller cities next to London. (Z, diary VI).

\section{Fragment 13}

(...) we also talked about the difference between our languages in America and in Europe. (S, diary VII).

These specific language aspects (dialects and accents and their status in society) were themes discussed during the TOS that were used by the professor to reinforce an item in the syllabus - the text written by Widdowson (1994) - "The ownership of English". The author discusses the authority of teachers in choosing one or another accent to teach as if there were only two possibilities in a real world and differences could easily be determined. The text also presents the false idea of teaching to sound as close to a native as possible, problematizing the role of native and non-native foreign language teachers. The syllabus also envisions a proposal to relate the content of Widdowson's text to Bernard Shaw's play "Pygmalion" and aims to discuss how speech reveals social, cultural, educational positions in society. The concept of "World Englishes" encompasses views about this debate. As Telles, Zakir, and Funo (2015) points out, it is essential that learners, teacher-mediators, and researchers pay attention to these culturerelated episodes in order for the teletandem setting to contribute to these learners' education. 
So far, the analysis shows how the professor used the learners' diaries as an integrating instrument by offering one-to-one feedback and collecting relevant topics to be addressed in the classroom, or, in other words, how teletandem practice (as it is perceived by these learners) can feed face-to-face language lessons by means of the professor's mediation. The following chart summarizes the results of this analysis:

FIGURE 1 - The professor's pedagogical procedures as she reads her learners' diaries

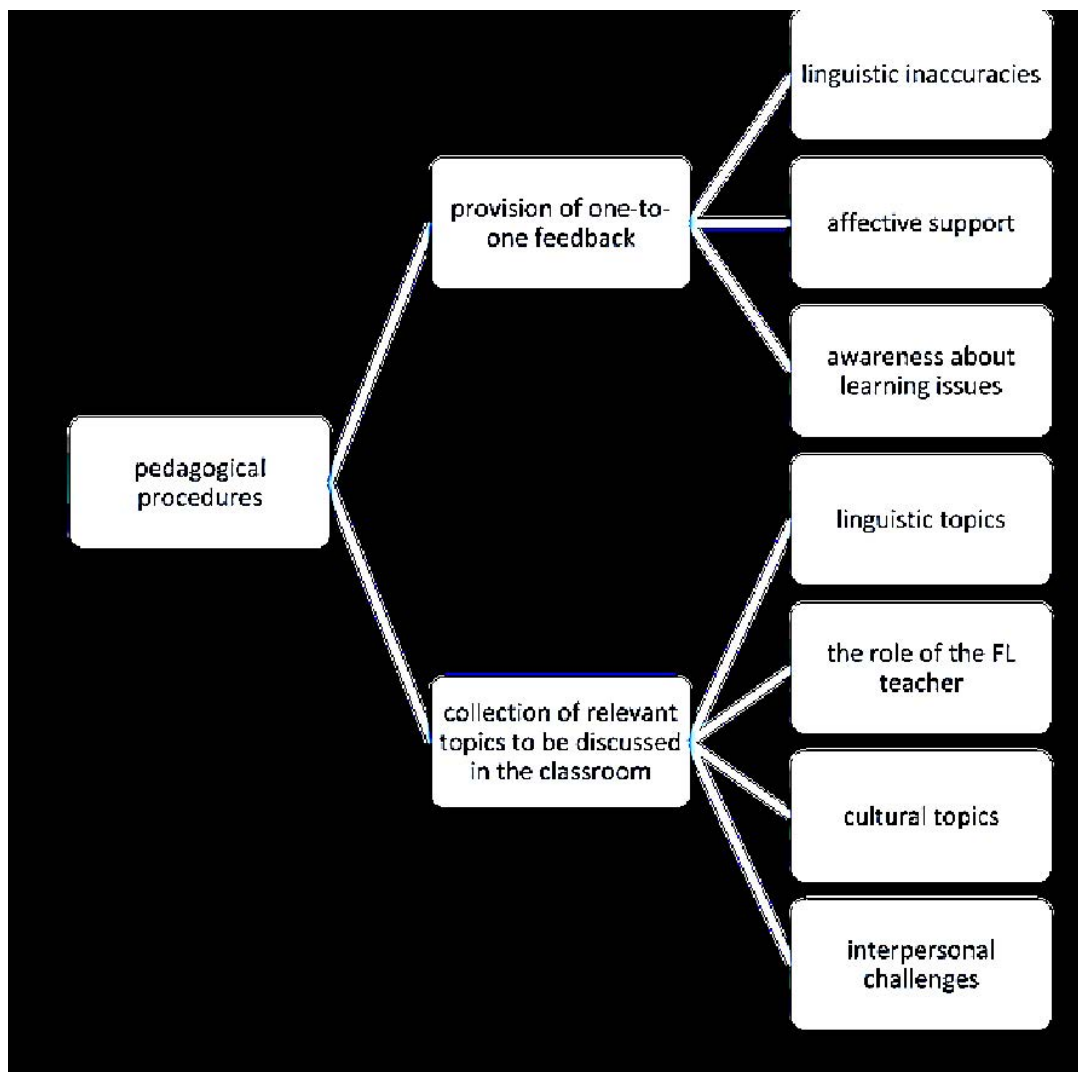

We understand that these pedagogical procedures bring to light the dual role of the professor in iiTTD, for they emphasize her actions both to teach EFL in her regular face-to-face lessons and to support autonomous and collaborative learning within teletandem. These procedures also highlight her responsibility in creating a meaningful connection between 
these two learning modes (online and face-to-face). If, on one hand, the private dialog that the professor establishes with the learner contributes to the mediation in groups, once it gives material for discussion, on the other, it may build strong bonds between the student and the professor because she can filter whether a specific piece of information may or should be shared. In this sense, it is essential that the teacher-mediator decides what might be kept private.

\subsection{What the teacher-mediator does so that the FL lessons feed teletandem}

In this part of the analysis, we examine how the professor, by reading the diaries, verifies whether the other microtasks are perceived by learners so that she can orchestrate the elements of the lessons that may feed teletandem practice. One of the microtasks that feed the macrotask TOS is the writing of texts related to the content of language classes. These texts vary according to themes and genres predicted in the syllabus. The activity requires that each participant writes a text in his/her foreign language and exchanges it with his/her partner to be corrected and discussed during TOS. This microtask is aimed to prevent difficulties shown by Luz (2012) and Garcia (2013) about the lack of topics to be discussed during the TOSs. M's and B's diaries reinforces the advantages of including such a microtask:

\section{Fragment 14}

Today wasn't so difficult because we had a text to correct so we could talk about it. In first interaction, sometimes we stay quiet because we didn't know what to say and it was terrible. (M, diary III).

\section{Fragment 15}

Today, our interaction was quickly because Emma had to go on a meeting with a professor of hers. We just opened my text file and read it together, discussing my errors. I learned a lot doing this. (B, diary IV).

We understand that these fragments corroborate what other studies (BONFIM, 2014; BROCCO, 2014; ARANHA; CAVALARI, 2015; CAVALARI, 2016; LUVIZARI-MURAD, 2016) have shown - that iiT'TD tasks may support foreign language learning and that peer feedback is highly valued by most participants. A key aspect of our analysis is the fact that the 
professor has a very important role to play as he/she puts the syllabus into practice by taking teletandem features into account.

The way the task is implemented seems to be relevant for student's learning. If, on one hand, lack of empathy or shared interests may become a barrier to learning, and these tasks may support the learning process, on the other, as O'Rourke (2007) points out, it is essential that participants have enough time to converse freely and discuss the topics they find relevant. For these reasons, the teacher should bear in mind that TOSs are the moments when learners can make choices about their own learning, and it is fundamental to understand and value those choices. Fragment 16 shows that the fact that learners do not need to discuss their peer's feedback during oral session is mentioned by $\mathrm{B}$ as a positive aspect.

\section{Fragment 16}

We started the interaction in Portuguese. As I have sent her my text, I thanked her for correcting it, but we haven't talked about it very much, because I understood her corrections, I had already read them in my house when she sent it to me. I could see that my mistakes are more about the uses of some prepositions, pronouns and the colocation of the words (DS, diary IV).

The diaries also informed the teacher about core aspects of the syllabus that could be learned collaboratively by means of text revision and discussion.

\section{Fragment 17}

After we talked very briefly about her text, she sent me a document that she researched about "which" and "that" that I had asked in the first interaction, and it was so nice, because she was very careful and remembered to do the search and she did it in Portuguese to me. (R, diary II).

This diary entry made the teacher anticipate a grammar topic (relative clauses), which would certainly be used by the students in their writings. The idea was to call her students' attention to this linguistic item so that they could use the text revision and the oral discussions to learn about the same topic in class (with the teacher) and in teletandem (with the peer).

Data suggest that incorporating classroom content into teletandem practice may be the most critical challenge to the professor in iiTTD. According to Nissen's (2016) study, it is substantial that the teacher creates 
a balance between the face-to-face and the virtual modes that constitute the course. These diary entries show students' perceptions on how classroom practice may have an impact in language learning in teletandem.

\section{Final remarks}

This study aimed to discuss the pedagogical implications of an integrated modality of teletandem (iiTTD), as implemented at UNESPSJRP, taking into consideration the professor's dual role: teaching FL in regular face-to-face lessons and mediating teletandem learning. In this sense, we analyzed how a Brazilian professor used students' diaries as a basis to integrate and harmonize the lessons and the online work.

The diaries gave the professor an insider perspective of the learning that was (not) taking place during TOSs and of the students' views on the iiT'TD experience. This was a key aspect to integrate the telecollaborative exchange into the FL program. Data showed that the private dialog established by the teacher-mediator and each learner fed the group discussion in mediation sessions and fostered the (re)organization of the contents addressed in the FL lessons. By the same token, the diaries revealed that the writing task that the professor proposed was perceived by her students as relevant for their learning process.

Data also showed that there seems to be a give and take relationship between the virtual exchanges and the classroom work that can only be achieved because of the professor's mediating role, in Vygotskian terms. The two-fold role gave her a more holistic perspective on her leaners' needs, and her flexibility to adapt the program seems to have created opportunities to act within the ZDP. In this sense, it is crucial to recognize that revising (the linguistics inaccuracies in learners' diaries by the professor and in the written texts in EFL by the foreign partners) is a way of promoting formative assessment and including different perspectives on the students' learning process.

Furthermore, considering that these participants are FL teachers-tobe, diaries were used by the professor to raise awareness about what to be a language teacher in different learning settings means and how improvement and awareness are an ongoing process.

In investigating what this teacher-mediator does within iiTTD, we understand it is not likely to separate which of her actions were solely 
intended to teach the contents predicted in the syllabus and which ones were aimed at supporting teletandem practice, for these two purposes seem interwoven. Moreover, we believe such weaving is possible because this professional's dual-role is guided by pedagogical procedures that are consistent with autonomous, intercultural, telecollaborative learning.

We acknowledge that these results must be corroborated by a study based on data from recordings of teachers' practice in the classroom. Freschi (forthcoming) is currently conducting a doctoral research, which will address these issues.

\section{Authors' contribution}

Solange Aranha has been responsible for collecting and organizing the data. Both authors contributed to the research conception and design, as well as to the analysis and interpretation of data. They both drafted and revised the manuscript. Suzi Cavalari was responsible for acting as the corresponding author. The final manuscript is a new work and does not include a literature review, data, or data analysis from previous dissertations or theses.

\section{References}

ANDREU-FUNO, L. Teletandem: um estudo sobre identidades culturais e sessões de mediação da aprendizagem. 2015. 191f. Tese (Doutorado em Estudos Linguísticos) - Universidade Estadual Paulista, São José do Rio Preto, 2015.

ARANHA, S.; CAVALARI, S. M. S. A trajetória do projeto Teletandem Brasil: da modalidade institucional não-integrada à institucional integrada. The ESPecialist, São Paulo, v. 35, n. 2, p.70-88, 2014.

ARANHA, S.; CAVALARI, S. M. S. Institutional Integrated Teletandem: what have we been learning about writing and peer feedback? DELT A, São Paulo, v. 31, n. 3, p. 763-780, 2015. Doi: https://doi.org/10.1590/0102-445039175922916369

ARANHA, S.; LEONE, P. The development of DOTI (Data of Oral Teletandem Interaction). In: FISER, D.; BEIßWENGER, M. (org.). Investigating computer-mediated communication: corpus-based approaches to language in the digital world. Ljubljana: University of Ljubljana, Faculty of Arts, 2017. v. 1. p. 172-192.

BONFIM, M. V. A autonomia no contexto teletandem institucional integrado. 2014. $94 \mathrm{f}$. Tese (Doutorado em Estudos Linguísticos) - Universidade Estadual Paulista, São José do Rio Preto, 2014. 
BROCCO, A. S. Avaliação de produções escritas em português como lingua estrangeira em contexto teletandem: contribuições para a formação de professores. 2014. 203f. Dissertação (Mestrado em Estudos Linguísticos) - Universidade Estadual Paulista, São José do Rio Preto, 2014.

CALVERT, M. The integration of email tandem learning into language courses. In: LITTLE, D.; BRAMMERTS, H. (ed.). A guide to language learning in Tandem via the Internet. Dublin: Trinity College Dublin, 1996. p. 35-42.

CAVALARI, S. M. S. Institutional integrated teletandem: students' perceptions about collaborative writing. Revista Entrelinguas, Araraquara, v. 2, n. 2, p. 249-260, 2016.

CAVALARI, S. M. S.; ARANHA, S. Teletandem: integrating e-learning into the foreign language classroom. Acta Scientiarum: Language and Culture, Maringá, v. 38, n. 4, p. 327-336, 2016. Doi: https://doi.org/10.4025/actascilangcult.v38i4.28139 DOOLY, M. Please remove your avatar from my personal space: competences of the Telecollaboratively Efficient Person. In: LEWIS, T.; O'DOWD, R. (ed.). Online Intercultural Exchange: Policy, Pedagogy, Practice. New York: Routledge, 2016. p. 192-208.

EUROPEAN COMMISSION. The lifelong learning programme 2007-2013. Glossary, 2008. Available at: http://ec.europa.eu/education/programmes/llp/ guide/ glossary_en.html. Retrieved on: Nov. 01, 2017.

FRESCHI, A. C. A avaliação porpares no teletandem institucional integrado: um estudo de caso sobre o feedback linguístico nas sessões orais em português. 2017. $212 \mathrm{f}$. Tese (Doutorado em Estudos Linguísticos) - Universidade Estadual Paulista, São José do Rio Preto, 2017.

FRESCHI, A. C. Telecolaboração e avaliação pelo professor: uma investigação sobre o teletandem institucional integrado. Tese (Doutorado em Estudos Linguísticos) Universidade Estadual Paulista, São José do Rio Preto. Forthcoming.

FUNO, L. B. A.; ELSTERMANN, A. K.; SOUZA, M. G. Fóruns no ambiente Teleduc: reflexões sobre o papel dos mediadores e estratégias de gerenciamento de debates. Revista Brasileira de Linguística Aplicada, Belo Horizonte, v. 15, n. 1, p. 31-59, 2015. Doi: http://dx.doi.org/10.1590/1984-639820156120

FURSTENBERG, G.; LEVET, S. Integrating telecollaboration into the language classroom: some insights. In: DOOLY, M.; O’DOWD, R. (ed.). Telecollaboration 2.0 for Language and Intercultural Learning. New York: Peter Lang Publishing Group, 2010. p. 305-336.

GARCIA, D. N. M. O que os pares de Teletandem (não) negociam. São Paulo: Editora UNESP, 2013. 216p. 
LEONE, P.; TELLES, J. A. The Teletandem Network. In: LEWIS, T.; O’DOWD, R. (ed.). Online Intercultural Exchange: Policy, Pedagogy, Practice. New York: Routledge, 2016. p. 243-248.

LEWIS, T. The Case for Tandem Learning. In: LEWIS, T.; WALKER, L. Autonomous Language Learning In-Tandem. Sheffield: Academy Electronic Publications, 2003. p. 13-25. Available at: http://oro.open.ac.uk/id/eprint/746. Retrieved on: June 21, 2018.

LEWIS, T. From Tandem Learning to E-Tandem Learning: How Languages Are Learnt in Tandem Exchanges. In Press.

LEWIS, T.; WALKER, L. (ed.). Autonomous Language Learning In-Tandem. Sheffield: Academy Electronic Publications, 2003. 241p.

LEWIS, T.; O'DOWD, R. (ed.). Online Intercultural Exchange: Policy, Pedagogy, Practice. New York: Routledge, 2016.308p. Doi: https://doi.org/10.4324/9781315678931

LITTLE, D.; BRAMMERTS, H. (ed.). A Guide to Language Learning in Tandem Via the Internet. Dublin: Trinity College Dublin, 1996. 87p.

LUVIZARI-MURAD, L. Ciclos de aprendizagem expansiva no processo de reorganização da coleta de dados em TTDii. 2016. 48 f. Relatório final (Pós-Doutorado em Estudos Linguísticos), Universidade Estadual Paulista, São José do Rio Preto.

LUZ, E. B. P. Variáveis influenciadoras da continuidade ou descontinuidade de parcerias de teletandem à luz da teoria da atividade. 2012. 274f. Tese (Doutorado em Estudos Linguísticos) - Universidade Estadual Paulista, São José do Rio Preto, 2012.

NISSEN, E. Combining Classroom-based Learning and Online Intercultural Exchange in Blended Learning Courses. In: LEWIS, T.; O'DOWD, R. (ed.). Online Intercultural Exchange: Policy, Pedagogy, Practice. New York: Routledge, 2016. p. 173-191.

O'DOWD, R. Telecollaborative networks in university higher education: overcoming barriers to integration. The Internet and Higher Education, Stanford, v. 18, n. 1, p. 47-53, 2013. Doi: https://doi.org/10.1016/j.iheduc.2013.02.001. Available at: http://www.sciencedirect.com/science/article/pii/S1096751613000110. Retrieved on: May 11, 2018.

O'ROURKE, B. Models of Telecollaboration: E(tandem). In: O'DOWD, R. (ed.). Online Intercultural Exchange: An Introduction for Foreign Language Teachers. Clevedon: Multilingual Matters, 2007. p. 41-62. 
SALOMÃO, A. C. B. A cultura e o ensino de lingua estrangeira: perspectivas para a formação continuada no projeto Teletandem. 2012. 268f. Dissertação (Mestrado em Estudos Linguísticos) - Universidade Estadual Paulista, São José do Rio Preto, 2012.

SALOMÃO, A. C. B. A formação do formador de professores: perspectivas de colaboração entre graduandos e pós-graduandos no projeto Teletandem Brasil. Revista Brasileira de Linguistica Aplicada, Belo Horizonte, v. 11, n. 3, p. 653-677, 2011. Doi: https://doi.org/10.1590/S1984-63982011000300004. Available at: http:// www.scielo.br/pdf/rbla/v11n3/04.pdf. Retrieved on: 12 maio 2018.

SILVA, R. F. Um estudo com foco no uso do diário reflexivo como instrumento de promoção da autonomia. 2014. 43f. Relatório final (Licenciatura em Letras) - Universidade Estadual Paulista, São José do Rio Preto, 2014.

TELLES, J. A. Learning foreign languages in Teletandem: resources and strategies. DELTA, São Paulo, v. 31, n. 3, p. 651-680, 2015. Doi: https://dx.doi. org/10.1590/0102-4450226475643730772

TELLES, J. A.; VASSALLO, M. L. Foreign language learning in-tandem: Teletandem as an alternative proposal in CALLT. The ESPecialist, São Paulo, v. 27, n. 2, p. 189-212, 2006. Available at: http:// citeseerx.ist.psu.edu/viewdoc/ download?doi=10.1.1.1025.2815\&rep=rep1\&type $=$ pdf. Retrieved on: May 11, 2018.

TELLES, J. A.; ZAKIR, M. A.; FUNO, L. B. A. Teletandem e episódios relacionados à cultura. DELT A, São Paulo, v. 31, n. 2, p. 359-389, 2015. Doi: https://dx.doi. org/10.1590/0102-445084549183239327

VIEIRA-ABRAHÃO, M. H. Teletandem Brasil: línguas estrangeiras para todos: um espaço para a formação de professores de línguas. In: BENEDETTI, A. M. B.; CONSOLO, D. A.; VIEIRA-ABRAHÃO, M. H. (ed.). Pesquisas em ensino e aprendizagem no Teletandem Brasil: línguas estrangeiras para todos. Campinas: Pontes Editores, 2010. p. 219-242.

VYGOTSKY, L. Mind in society: The Development of Higher Psychological Processes. Cambridge: Harvard University Press, 1978. 159p.

WIDDOWSON, H. G. The Ownership of English. TESOL Quarterly, Washington, v. 28, n. 2, p. 377-389, 1994. Doi: https://doi.org/10.2307/3587438

Data de submissão: 07/05/2018. Data de aprovação: 14/03/2019. 